\title{
Effect of Hospital Conditions on Short-Term Colorectal Cancer Outcomes: Experience of One Surgeon in Two Centers
}

\section{Hastane Koşullarının Erken Dönem Kolorektal Kanser Sonuçlarına Etkisi: Tek Cerrah, İki Merkez}

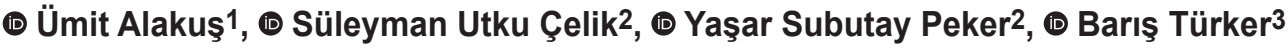 \\ 1 University of Health Sciences, Gülhane Training and Research Hospital, Clinic of Surgical Gastroenterology, Ankara, Turkey \\ 2University of Health Sciences, Gülhane Training and Research Hospital, Clinic of General Surgery, Ankara, Turkey \\ ${ }^{3}$ Eskişehir Osmangazi University Faculty of Medicine, Health Practice and Research Hospital, Clinic of Surgical Gastroenterology, Eskişehir, Turkey
}

\section{HIIIIII ABSTRACT}

\begin{abstract}
Aim: Many factors can affect the outcomes of colorectal cancer (CRC) surgery. In addition to patient- and disease-related outcomes, factors such as surgeon volume and hospital conditions are thought to influence the results. However, only a few studies have compared the experience of a single surgeon from different centers. Thus, this study aimed to compare the short-term outcomes of CRC surgery performed by a single surgeon in secondary care (state hospital) and tertiary care (university/training research hospital) centers.

Method: Data of patients who received treatment for colon cancer between April 2018 and January 2020 by a single surgeon, who had completed gastroenterology surgery fellowship, in two different centers were retrospectively analyzed. Patients were divided into two groups as those treated in a secondary center and a tertiary center and compared in terms of demographic characteristics, application types, cancer stage, perioperative transfusion requirement, operation conditions, durations of hospital and intensive care stay, postoperative complications, and pathology results.

Results: Of the 39 patients included in the study, 13 (33.3\%) were treated in a secondary state hospital and 26 (66.7\%) in a tertiary training and research hospital. Moreover, $46.2 \%$ of the patients in the secondary center group and $11.5 \%$ of the patients in the tertiary center group underwent emergency surgery because of ileus. The transfusion rate was higher in the secondary center group than in the tertiary center group (76.9\% vs $34.6 \%$ ). The rate of laparoscopic surgery was higher in the tertiary center group than in the secondary center group (7.7\% vs $69.2 \%$ ). No significant difference was found between the two centers in terms of demographic characteristics, length of hospital stay, complications, and pathology results.

Conclusion: Although the application rates are higher in advanced disease stages and emergency conditions, provided that the experience and training of the surgeon is sufficient, colorectal cancer surgery can be performed in relatively small and low-volume centers, with oncological results, morbidity, and mortality rates similar to those of large centers.
\end{abstract}

Keywords: Colon cancer, postoperative outcomes, hospital volume

\section{|l||l||l|| ÖZ}

Amaç: Kolorektal kanser (KRK) cerrahisinin sonuçlarını etkileyen birçok faktör vardır. Hasta ve hastalık kaynaklı sonuçların yanı sıra cerrah volümü ve hastane koşulları gibi faktörlerin de sonuçlara etkisi olduğu düşünülmektedir. Ancak literatürde tek cerrahın farklı merkezlerdeki sonuçlarını karşılaştıran yeterince çalışma yoktur. Bu çalışmanın amacı tek cerrah tarafından 2. basamak (devlet hastanesi) ve 3. basamak (üniversite/eğitim araştırma hastanesi) merkezlerde yapılan KRK olgularının erken dönem sonuçlarını karşılaştırmaktır.

Yöntem: Çalışmada gastroenteroloji cerrahisi yan dal eğitimi alan tek cerrah tarafından koşulları farklı iki merkezde Nisan 2018-Ocak 2020 tarihleri arasında kolon kanseri nedeniyle tedavi edilen hastalar retrospektif olarak incelendi. Hastalar 2. ve 3. basamak merkezde tedavi olanlar olarak iki gruba ayrılarak demografik özellikleri, başvuru şekilleri, kanser evresi, perioperatif transfüzyon ihtiyacı, ameliyat şartları, hastane ve yoğun bakım yatış süreleri, postoperatif komplikasyonlar ve patoloji sonuçları açısından karşılaştırıldı.

Bulgular: Çalışmaya alınan 39 hastanın 13'ü $(\% 33,3)$ 2. basamak devlet hastanesinde, 26’sı $(\% 66,7)$ 3. basamak eğitim ve araştırma hastanesinde tedavi edildi. İkinci basamak merkezde opere edilen hastaların \%46,2'si, 3. basamaktakilerin \%11,5’i ileus nedeniyle acil şartlarda opere edildi.

Address for Correspondence/Yazışma Adresi: Ümit Alakuş, MD,

University of Health Sciences, Gülhane Training and Research Hospital, Clinic of Surgical Gastroenterology, Ankara, Turkey

E-mail: umitalakus@yahoo.com ORCID ID: orcid.org/0000-0002-6756-3583

Received/Geliş Tarihi: 10.12.2020 Accepted/Kabul Tarihi: 04.01.2021

${ }^{\circ}$ Copyright 2021 by Turkish Society of Colon and Rectal Surgery

Turkish Journal of Colorectal Disease published by Galenos Publishing House. 
Transfüzyon oranı 2. basamak merkezde daha yüksek bulundu (\%76,9'a karşı \%34,6). Üçüncü basamak merkezde ise laparoskopik cerrahi oranı daha yüksekti $(\% 7,7$ ye karşı \%69,2). Demografik özellikler, hastane yatış süreleri, komplikasyonlar ve patoloji sonuçları açısından iki merkez arasında anlamlı fark saptanmadı.

Sonuç: İleri evre ve acil şartlarda başvuru oranları daha yüksek olsa da cerrahın tecrübe ve eğitiminin yeterli olması durumunda kolorektal kanser cerrahisi, nispeten küçük ve volümü düşük merkezlerde de büyük merkezlere benzer onkolojik sonuçlar, morbidite ve mortalite oranları ile uygulanabilir.

Anahtar Kelimeler: Kolon kanseri, postoperatif sonuçlar, hastane volümü

\section{Introduction}

There are many factors that affect the results of colorectal cancer (CRC) surgery. In addition to patient and diseaserelated outcomes, factors such as surgeon volume and hospital conditions are thought to have an impact on the results. Depending on the annual number of patients, education, and branching, CRC-specific survival rates at 5 years following curative resection range from $53 \%$ to $85 \%{ }^{1}$ Bilimoria et al. ${ }^{2}$ investigated the effect of surgeon and hospital volumes on patient outcomes in various cancers in a study they designed. This study showed that patients operated in high-volume centers and by high-volume surgeons have better outcomes than patients operated in lower-volume centers and by surgeons with lower number of patients. ${ }^{2,3}$ Evidence that CRC outcomes may depend on more than volume alone has come from research showing that hospitals designated by the National Cancer Institute have superior long-term survival compared to other hospitals. ${ }^{4}$ Porter et al. ${ }^{5}$ evaluated the results of lower anterior resection and abdominoperineal resection procedures performed in a period of approximately 8 years in their study which they designed as a multicenter study. They examined the surgeons in two groups as those who received additional training on CRC (surgical oncology, colorectal surgery subspecialty, etc.) and those who did not and as a result, they concluded that more experienced surgeons and specialized surgeons had positive effects on cancer-specific survival. In another study, a reduction in postoperative complications and longterm survival were found in patients who were operated by surgeons who had a special training for rectal cancer. ${ }^{6}$ Billingsley et al. $^{7}$ argued that very high surgeon volume was associated with a reduction in surgical complications, but the relationship between increased hospital volume and postoperative mortality was mainly related to clinical services that could facilitate early recognition and treatment of complications.

In the literature, the effects of hospital volume, annual number of patients of the surgeon, whether the surgeon has received specific training on this subject, and even the age of the surgeon on the early and long-term outcomes of CRC surgery have been frequently investigated. ${ }^{8}$ In these studies, although the details are not mentioned, the anesthesia, oncology, radiology and pathology teams that contribute to the patient's treatment process may be fixed for surgeons performing procedures. However, when evaluated specifically for the surgical treatment of CRC, studies comparing the results of a single surgeon in centers with different volumes are limited.

As it is known, surgeons, like all doctors, are assigned to hospitals with different volumes and facilities by the Ministry of Health in our country for various reasons such as state service obligation or spouse status. In this study, it was aimed to compare the results of patients who underwent surgical treatment for colon cancer in separate secondary and tertiary centers by a surgeon who completed his training in gastroenterology surgery, and to reveal the effect of the volume and facilities of the centers on these results.

\section{Materials and Methods}

The study was conducted in accordance with the principles of the Declaration of Helsinki and with the approval of the local ethics committee (ethics committee number: 2020/241). Written informed consent form was obtained from all patients included in the study at the time of admission. In the study, patients who were treated for colon cancer between April 2018 and January 2020 in two centers under different conditions by a single surgeon with subspecialty training in gastroenterology surgery were retrospectively analyzed.

The patients were divided into two groups according to the centers where their surgical treatment was performed: State hospital ( $2^{\text {nd }}$ level) and training and research hospital ( $3^{\text {rd }}$ level). Only adult patients were included in the study. Patients receiving neoadjuvant therapy and patients treated for rectal cancer were excluded from the study. Groups were compared in terms of demographic characteristics (such as age and gender), presence of preoperative obstruction, emergency or elective surgery, preoperative hemoglobin values, perioperative blood transfusion status, tumor localization, surgical technique applied, duration of surgery, postoperative complications, tumor stage, metastatic, total lymph node number, and postoperative hospitalization durations in intensive care unit and ward. 


\section{Surgical Technique}

In all surgeries, total mesocolic excision was performed in accordance with oncological principles. The risk of anastomotic leakage of patients who were operated on with signs of obstruction in emergency conditions was evaluated intraoperatively, and in patients deemed necessary, anastomosis was not performed and stoma was created.

\section{Statistical Analysis}

SPSS version 15.0 (Statistical Package for the Social Sciences Inc., Chicago, IL, USA) was used to evaluate the data obtained from the study. Obtained values are shown as mean \pm standard deviation and percentage (\%) where appropriate. Chi-square test was used to compare categorical variables. In the comparison of two independent groups; Student's t-test was used when normal distribution was met, and MannWhitney U-Test was used when normal distribution was not met. In all statistical analyses, the level of significance was accepted as $\mathrm{p}<0.05$.

\section{Results}

A total of 39 patients who were operated for colon cancer in a 22-month period were included in the study. While 13 of

Table 1. Demographic and clinical characteristics of the patients

\begin{tabular}{|c|c|c|c|}
\hline & $\begin{array}{l}\text { State hospital } \\
(\mathrm{n}=13)\end{array}$ & $\begin{array}{l}\text { Training and research hospital } \\
(\mathrm{n}=26)\end{array}$ & $\mathrm{p}$ \\
\hline Age (year) & $64.1 \pm 16.4$ & $62.6 \pm 13.5$ & 0.769 \\
\hline Gender, n (\%) & & & 0.365 \\
\hline Female & $8(61.5)$ & $12(46.2)$ & \\
\hline Male & $5(38.5)$ & $14(53.8)$ & \\
\hline Type of surgery, n (\%) & & & 0.024 \\
\hline Emergency & $6(46.2)$ & $3(11.5)$ & \\
\hline Elective & $7(53.8)$ & $23(88.5)$ & \\
\hline Tumor location, n (\%) & & & 0.092 \\
\hline Cecum-ascending colon & $2(15.4)$ & $6(23.1)$ & \\
\hline Transverse colon & $4(30.8)$ & $2(7.7)$ & \\
\hline Descending colon & $3(23.1)$ & $2(7.7)$ & \\
\hline Sigmoid colon & $4(30.8)$ & $16(61.5)$ & \\
\hline Preoperative ileus, n (\%) & $6(46.2)$ & $3(11.5)$ & 0.024 \\
\hline Preoperative $\mathrm{Hb}<10 \mathrm{~g} / \mathrm{dL}, \mathrm{n}(\%)$ & $4(30.8)$ & $6(23.1)$ & 0.440 \\
\hline Laparoscopic surgery, n (\%) & $1(7.7)$ & $18(69.2)$ & $<0.001$ \\
\hline Duration of surgery (min) & $166 \pm 30$ & $211 \pm 84$ & 0.099 \\
\hline Perioperative blood transfusion, $\mathbf{n}(\%)$ & $10(76.9)$ & $9(34.6)$ & 0.013 \\
\hline
\end{tabular}

the patients (33.3\%) were operated in the second level state hospital; 26 (66.7\%) of them were operated by the same surgeon in a tertiary training and research hospital. Of the patients, 19 (48.7\%) were male and 20 were female, and their mean age was $63.1 \pm 14.3$. There was no difference between the two centers in terms of demographic characteristics. Compared to colon cancer procedures performed at the tertiary center, procedures performed at the secondary center were more performed in emergencies (46.2\% vs $11.5 \%$; $\mathrm{p}=0.024)$ and required more perioperative erythrocyte suspension $(76.9 \%$ vs $34.6 \%$; $\mathrm{p}=0.013)$. While laparoscopic procedures were mostly preferred in the tertiary center; the rate of open surgery was higher in the secondary center $(p<0.001)$. There was no significant difference between the groups in terms of tumor localization and duration of surgery (Table 1). The pathology results of the groups were compared in Table 2. There was no difference between centers in terms of total number of lymph nodes resected ( $\mathrm{p}=0.353)$, number of positive lymph nodes $(\mathrm{p}=0.627), \mathrm{T}$ stage $(\mathrm{p}=0.068), \mathrm{N}$ stage $(\mathrm{p}=0.639), \mathrm{M}$ stage $(\mathrm{p}=0.337)$, and tumor stages $(\mathrm{p}=0.608)$. Although no significant difference was found, there was evidence showing that patients who were admitted to the secondary center were admitted at

Hb: Hemoglobin 
a more advanced stage. Some of these evidences were as follows: Patients diagnosed as having colon cancer were statistically significantly more admitted with ileus (46.2\% vs $11.5 \% ; \mathrm{p}=0.024$ ), and although not statistically significant, more metastatic disease, and more stage 4 cancer were found. End colostomy was performed in three patients who were operated under emergency conditions in the secondary hospital. Again under emergency conditions, extended left hemicolectomy was performed in one patient and a loop ileostomy was created by simultaneous anastomosis with subtotal colectomy in another patient. In the tertiary center, resection anastomosis was performed in all surgeries. There was no difference between centers in terms of complications evaluated with the Clavien-Dindo classification $(\mathrm{p}=0.325)$. Wound infection in one patient and intra-abdominal abscess in one patient in the state hospital were treated with medication. In the training and research hospital, 3 intra-

Table 2. Comparison of centers in terms of pathology results

\begin{tabular}{|c|c|c|c|}
\hline & $\begin{array}{l}\text { State hospital } \\
(\mathrm{n}=13)\end{array}$ & $\begin{array}{l}\text { Training and research hospital } \\
(\mathrm{n}=26)\end{array}$ & $\mathrm{p}$ \\
\hline Positive surgical margin, $\mathrm{n}(\%)$ & & & NS \\
\hline No & $13(100)$ & $26(100)$ & \\
\hline Yes & 0 & 0 & \\
\hline Total number of lymph nodes & $19.0 \pm 8.3$ & $23.6 \pm 13.1$ & 0.353 \\
\hline Number of positive lymph nodes & $2.7 \pm 3.6$ & $2.4 \pm 3.6$ & 0.627 \\
\hline T stage, $\mathrm{n}(\%)$ & & & 0.068 \\
\hline $\mathrm{T} 1$ & 0 & 0 & \\
\hline $\mathrm{T} 2$ & $3(23.1)$ & $2(7.7)$ & \\
\hline T3 & $4(30.8)$ & $18(69.2)$ & \\
\hline $\mathrm{T} 4$ & $6(46.1)$ & $6(23.1)$ & \\
\hline N stage, n (\%) & & & 0.639 \\
\hline NO & $4(30.8)$ & $10(38.4)$ & \\
\hline N1 & $6(46.1)$ & $8(30.8)$ & \\
\hline $\mathrm{N} 2$ & $3(23.1)$ & $8(30.8)$ & \\
\hline M stage, n (\%) & & & 0.337 \\
\hline M0 & $9(69.2)$ & $21(80.8)$ & \\
\hline M1 & $4(30.8)$ & $5(19.2)$ & \\
\hline Tumor (TNM) stage, $\mathbf{n}(\%)$ & & & 0.608 \\
\hline Stage I & $2(15.4)$ & $2(7.7)$ & \\
\hline Stage II & $2(15.4)$ & $8(30.8)$ & \\
\hline Stage III & $5(38.4)$ & $11(42.3)$ & \\
\hline Stage IV & $4(30.8)$ & $5(19.2)$ & \\
\hline
\end{tabular}

abdominal abscesses and wound infection, anastomotic leakage, prolonged ileus and bleeding were detected in one patient. While no statistically significant difference was observed in hospitalization times and 30-day reoperation rates, the duration of intensive care unit stay was longer in the tertiary care center ( 1.6 vs. $3.1 ; \mathrm{p}=0.047$ ).

\section{Discussion}

The period in which the study was carried out was a total of 22 months, the first six months of which covered the secondary center and the remaining 16 months covered the process in the tertiary center. The secondary center was in Batman, located in the Southeastern Anatolia region of Turkey and the tertiary center was located in Ankara. Therefore, while the study reflects the difference between centers at different levels; on the other hand, it is important in terms

\section{State hospital}


of presenting a perspective in terms of regional differences. In our study, the rate of patients who presented with ileus and therefore underwent emergency surgery was higher in the secondary center. Perioperative transfusion rate was statistically significantly higher in the secondary center. In addition, while the rate of $\mathrm{T} 4$ stage cancer in the secondary center was $46.1 \%$; in the tertiary center, this rate was $23.1 \%$. These findings can be interpreted as patients diagnosed as having colon cancer tend to prefer advanced centers more frequently after diagnosis, or it can be interpreted that the rate of emergency surgery may be due to diagnostic delays due to socioeconomic and cultural reasons. Because, according to the socioeconomic development ranking research (SEGE2017) of the city where the secondary center was located in our study ${ }^{9}$, it was in the sixth stage developed province groups; while the city where the tertiary center was located was in the first stage developed province group. In addition, considering the two regions where the study was conducted, it was inevitable that there would be differences in terms of CRC screening awareness. This was compatible with the fact that patients in the secondary center were admitted to the hospital in a more advanced stage. Aquina et al. ${ }^{10}$ found a $62.8 \%$ variation in the use of minimally invasive methods in colon surgery suggesting that this was mostly due to surgeons $(28.5 \%)$, followed by hospital characteristics $(7 \%)$, and finally geographical features (1.6\%). However, the approach of the same surgeon in different centers in this study was not clearly stated. When surgical procedures were evaluated in our study, the rate of laparoscopic surgery was

Table 3. Comparison of centers in terms of postoperative results statistically significantly higher in the tertiary center. The material facilities of the tertiary hospital, the experience of the assistant staff in minimally invasive surgery, the high rate of elective surgery and patient demands could be considered as the reasons why laparoscopic surgery was more preferred. In a single-center study conducted by Barbas et al. ${ }^{11}$ in which the results of CRC surgery performed by the surgeons with and without surgical oncology training were compared; the rate of lymph node dissection unsuitable for oncologic surgery (less than 12) was found to be statistically higher in surgeons who did not receive appropriate training. In this study, they concluded that the training received by the surgeon was more important than the volume of the surgeon. Martínez-Ramos et al. ${ }^{12}$ showed in a singlecenter study comparing the results of general surgeons and colorectal surgeons that the mean number of lymph nodes dissected by surgeons in both groups was below 12 and there was no difference in patient outcomes between the groups. Nathan et al. ${ }^{13}$ reported that the rate of inadequate lymph node dissection was at a substantial level, which could be attributed to surgeons (8\%), pathologists (19\%), and hospitals $(73 \%)$, respectively, after excluding patient characteristics. In our study comparing the results of different centers of the same surgeon, the number of dissected lymph nodes was found to be 19 and 23 in the secondary and tertiary level centers, respectively, and they were oncogically sufficient. In pathological examinations, there was no difference between centers in terms of factors

State hospital
$(\mathrm{n}=13)$

Clavien-Dindo classification, $\mathrm{n}(\%)$

None

Grade I-II

Grade III-V

Complications, n (\%)

Anastomotic leak

Intraabdominal abscess

Prolonged postoperative ileus

Bleeding

Wound infection

Length of intensive care unit stay (days)

Length of hospital stay (days)

30-day reoperation, n (\%)

\section{$(\mathrm{n}=13)$}

$11(84.6)$

$2(15.4)$

0

-
1
-
-
1
$1.6 \pm 1.9$
$10.4 \pm 4.8$
$1(7.7)$

Training and research hospital $(\mathrm{n}=26)$

$19(73.1)$

$3(11.5)$

$4(15.4)$

1

3

1

1

1

$3.1 \pm 3.7$

0.047

$10.8 \pm 8.1$

0.187

3 (11.5)

1.000

NS: Not significant 
indicating compliance with oncological principles such as surgical margin, number of removed lymph nodes, and it was evaluated that the treatment applied in the two centers was similar in terms of oncological results. It was evaluated that the high $\mathrm{T} 4$ and metastatic disease rates in the secondary center may be related to the patients' preferences for admission or inadequacy in screening.

Brännström et al. ${ }^{14}$ examined the effect of surgeon and hospital-related factors on the outcome of CRC surgery. They suggested that the results were not related to hospital category, surgeon volume, or the specialized training of the surgeon, and that the most important factor influencing outcomes in colon surgery was the stage of the disease. In a single-center study conducted by Barbas et al. ${ }^{11}$, there was no effect of having surgical oncology training on 30, 60, and 90day perioperative mortalities; while a statistically significant effect on overall survival was reported. This situation was associated with inadequate surgical oncology practice in the group who did not receive any training. Xu et al. ${ }^{15}$ reported in their study that the rate of postoperative complications was related to the surgeon rather than the hospital. Billingsley et al. ${ }^{7}$ found the postoperative 30-day morbidity and mortality rates similar and reported that the most effective factor in this regard was the volume of the surgeon, not the center. While no early mortality was found in our study; no significant difference was found in terms of complications, length of hospital stay, and, 30-day reoperation rate. In the current study, the difference in length of stay in intensive care unit might be due to the shorter post-operative intensive care unit stay in the secondary step center and the necessity of providing rapid circulation due to the low intensive care unit capacity in small centers. However, this situation does not have a negative effect on clinical patient outcomes and may contribute positively to the cost and faster psychological normalization of the patients.

Although the primary goal in this study was to evaluate the effects of centers on CRC surgery outcomes; on the other hand, we obtained data related to patient preferences and awareness in the peripheral and central regions of our country. In conclusion, there was no difference in terms of early results of CRC surgery between the secondary center located in the periphery of Turkey and the tertiary care center located at the central point. However, as discussed above, there were significant differences between centers in terms of patient presentation and disease stage, probably due to socioeconomic and cultural reasons or the tendency of patients to prefer advanced centers after cancer diagnosis.

\section{Study Limitations}

The main limitations of the study were that the evaluation was based on retrospective data, that the number of patients was relatively small due to the limited time in the institutions worked, and that only short-term results were evaluated. Our group continued the follow-up of the patients and planned to publish the long-term results. Since the study was planned to compare the results of the same surgeon in two centers with different volumes, capacities and facilities, we were not able to expand the parameters except for longterm results. In the tertiary center where the surgeon was still working, we will have the opportunity to increase the number of patients in the future. However, since it is not possible for the same surgeon to work again in the secondary center, it does not seem possible for us to increase the number of patients in this center. Although fewer colon cancer surgeries despite longer duration of working in the secondary center is considered as a limitation, we think that it can also be considered as one of the results showing the difference between the centers. The fact that the centers are located in different geographical regions can be considered as another limitation. However, since this is a regulation related to the health system in our country, it is almost impossible to optimize.

These limitations can be eliminated with studies that are prospectively designed with a larger number of patients and eliminate regional differences, and more reliable results can be obtained in this regard. The experience and education of the surgeon are among the most important factors affecting the results of CRC surgery. Although the admission rates are higher in advanced stages and in emergency conditions, CRC surgery can be safely performed in relatively small and low-volume centers with similar oncological results, postoperative morbidity and mortality rates with highvolume centers, if the surgeon's experience and training is sufficient. However, differences in regional awareness and inadequacies regarding CRC and screening still remain relevant for our country.

\section{Ethics}

Ethics Committee Approval: The study was conducted in accordance with the principles of the Declaration of Helsinki and with the approval of the local ethics committee (ethics committee number: 2020/241).

Informed Consent: Written informed consent form was obtained from all patients included in the study at the time of admission.

Peer-review: Externally and internally peer reviewed.

\section{Authorship Contributions}

Surgical and Medical Practices: Ü.A., Concept: Ü.A., S.U.Ç., Y.S.P., B.T., Design: Ü.A., S.U.C.., B.T., Data Collection or Processing: Ü.A.,Y.S.P., B.T., Analysis or Interpretation: Ü.A., S.U.Ç., Y.S.P., B.T., Literature Search: Ü.A., S.U.Ç., Y.S.P., B.T., Writing: Ü.A., S.U.Ç., Y.S.P., B.T. 


\section{Conflict of Interest: No conflict of interest was declared by} the authors.

Financial Disclosure: The authors declared that this study received no financial support.

\section{References}

1. McArdle CS, Hole DJ. Influence of volume and specialization on survival following surgery for colorectal cancer. Br J Surg 2004;91:610-617.

2. Bilimoria KY, Bentrem DJ, Feinglass JM, Stewart AK, Winchester DP, Talamonti MS, Ko CY. Directing surgical quality improvement initiatives: comparison of perioperative mortality and long-term survival for cancer surgery. J Clin Oncol 2008;26:4626-4633.

3. Stocchi L, Nelson H, Sargent DJ, O'Connell MJ, Tepper JE, Krook JE, Beart R Jr; North Central Cancer Treatment Group. Impact of surgical and pathologic variables in rectal cancer: a United States community and cooperative group report. J Clin Oncol 2001;19:3895-3902.

4. Paulson EC, Mitra N, Sonnad S, Armstrong K, Wirtalla C, Kelz RR, Mahmoud NN. National Cancer Institute designation predicts improved outcomes in colorectal cancer surgery. Ann Surg 2008;248:675-686.

5. Porter GA, Soskolne CL, Yakimets WW, Newman SC. Surgeon-related factors and outcome in rectal cancer. Ann Surg 1998;227:157-167.

6. Read TE, Myerson RJ, Fleshman JW, Fry RD, Birnbaum EH, Walz BJ, Kodner IJ. Surgeon specialty is associated with outcome in rectal cancer treatment. Dis Colon Rectum 2002;45:904-914.

7. Billingsley KG, Morris AM, Dominitz JA, Matthews B, Dobie S, Barlow W Wright GE, Baldwin LM. Surgeon and hospital characteristics as predictors of major adverse outcomes following colon cancer surgery: understanding the volume-outcome relationship. Arch Surg 2007;142:23-31; discussion 32.
8. Johnson FE, Novell LA, Coplin MA, Longo WE, Vernava AM, Wade TP, Virgo KS. How practice patterns in colon cancer patient follow-up are affected by surgeon age. Surg Oncol 1996;5:127-131.

9. Acar S, Meydan MC, Bilen Kazancık L, Ișık M. İllerin ve Bölgelerin SosyoEkonomik Gelişmişlik Sıralaması Araştırması Sege-2017. T.C. Sanayi ve Teknoloji Bakanlı̆̆ı Kalkınma Ajansları Genel Müdürlüğü. Erişim Adresi: https://www.bebka.org.tr/admin/datas/sayfas/89/sege-2017_1581687211. pdf.

10. Aquina CT, Becerra AZ, Justiniano CF, Xu Z, Boscoe FP, Schymura MJ, Noyes K, Monson JRT, Temple LK, Fleming FJ. Surgeon, Hospital, and Geographic Variation in Minimally Invasive Colectomy. Ann Surg 2019;269:1109-1116

11. Barbas AS, Turley RS, Mantyh CR, Migaly J. Effect of surgeon specialization on long-term survival following colon cancer resection at an NCIdesignated cancer center. J Surg Oncol 2012;106:219-223.

12. Martínez-Ramos D, Escrig-Sos J, Miralles-Tena JM, Rivadulla-Serrano MI, Daroca-José JM, Salvador Sanchís JL. Influencia de la especialización del cirujano en los resultados tras cirugía por cáncer de colon. Utilidad de los índices de propensión (propensity scores) [Influence of surgeon specialization upon the results of colon cancer surgery. Usefulness of propensity scores]. Rev Esp Enferm Dig 2008;100:387-392. (Spanish)

13. Nathan H, Shore AD, Anders RA, Wick EC, Gearhart SL, Pawlik TM. Variation in lymph node assessment after colon cancer resection: patient, surgeon, pathologist, or hospital? J Gastrointest Surg 2011;15:471-479.

14. Brännström F, Jestin P, Matthiessen P, Gunnarsson U. Surgeon and hospital-related risk factors in colorectal cancer surgery. Colorectal Dis 2011;13:1370-1376.

15. Xu T, Makary MA, Al Kazzi E, Zhou M, Pawlik TM, Hutfless SM. Surgeonlevel variation in postoperative complications. J Gastrointest Surg 2016;20:1393-1399. 